\title{
Alternative Substrates Formulated with Agro-Industrial Residues for Forest Species Seedling Production
}

\author{
Luciana Samuel Nhantumbo ${ }^{1}$ (D) \\ Maristela Machado Araujo ${ }^{2}$ \\ Maria Helena Fermino ${ }^{3}$ \\ Suelen Carpenedo Aimi $^{2}$ (D) \\ Adriana Maria Griebeler ${ }^{2}$ (D)
}

\begin{abstract}
This study aimed to evaluate different container sizes and substrates formulated with agro-industrial residues to produce Handroanthus heptaphyllus and Schinus terebinthifolius seedlings. The experiment had a completely randomized design with four replications (48 seedlings each), in a factorial scheme (containers $\times$ substrates), with two containers $\left(110\right.$ and $180 \mathrm{~cm}^{3}$ ) and ten substrates (agro-industrial residues (crushed peach pits and peel rice) mixed with organic compost). Carbonized and hydrolyzed rice husk (CRH and HRH, respectively) were used. At 90 and 108 days after the emergence of the $S$. terebinthifolius and $H$. heptaphyllus seedlings, the morphophysiological attributes were evaluated. Considering the attributes evaluated in this study, the $180 \mathrm{~cm}^{3}$ container promoted more significant seedling growth for both species. Substrates containing up to $20 \% \mathrm{CRH}, \mathrm{HRH}$, or crushed peach pits (CPP) are indicated for S. terebinthifolius, and those with up to $30 \% \mathrm{CRH}$ or $10 \% \mathrm{HRH}$ or CPP are indicated for H. heptaphyllus.
\end{abstract}

Keywords: Carbonized rice husk, hydrolyzed rice husk, crushed peach pits, morphophysiological attributes, seedling quality.

\section{INTRODUCTION AND OBJECTIVES}

Seedling production is one of the most critical stages for establishing forest crops being dependent on the use of good quality substrates (Silva et al., 2014). Agricultural and industrial practices produce large amounts of wastes that can be rich in nutrients or have essential properties (aeration space, porosity and water availability) for plant cultivation (Vieira, 2014). Research is currently investigating sustainable and low-cost alternatives for seedling production (Mieth et al., 2018; Fermino et al., 2018). Thus, studies have focused on reusing waste for substrate formulation to recycle their nutrients and mitigate adverse environmental impacts (Araujo et al., 2017).

For example, rice husk is one of the most produced and available residues, as it comes from one of the most consumed crops worldwide (Kratz, 2011; Bonaguro et al., 2017). Carbonized rice husk (CRH) can be used in the composition of substrates (Islabão, 2014), as it improves physical characteristics in dry or humid conditions, such as aeration space, drainage, and constant volume (Chu et al., 2007).

Peach (Prunus persica) cultivation is another agricultural activity producing residues, common in small family farms intended to commercialize the fresh fruits to canning industry (Protas \& Madail, 2003). The seed is one of the residues from the industrial processing of peach, consisting of an almond used to extract cosmetic oil and has a high calorific value, while the pericarp is used as material for power generation (Diniz et al., 2004). Mieth et al. (2018) and Fermino et al. (2018) studied the peach kernel as a substrate component, as when crushed, it can be used to improve the substrate physical characteristics while reducing costs.

The substrate is essential for seedling quality. Therefore, it is necessary to determine its physical, chemical, and biological properties to guarantee the morphological and physiological quality of the produced seedlings (Kratz, 2015), particularly the physical properties that cannot be modified during cultivation (Araujo et al., 2018).

${ }^{1}$ Universidade Lúrio (UniLúrio), Faculdade de Ciências agrárias (FCA), Nampula, Mozambique

${ }^{2}$ Universidade Federal de Santa Maria (UFSM), Departamento de Ciências Florestais, Santa Maria, RS, Brasil

${ }^{3}$ Secretaria da Agricultura Pecuária e Agronegócio, Departamento de Diagnóstico e Pesquisa Agropecuária, Porto Alegre, RS, Brasil 
The container must also be considered in seedling production. According to Landis (1990), its choice depends on seed size, seedling dispatch size, and the root system morphology. Among the various containers available on the market, polypropylene tubes are widely used owing to the direction and pruning of the root system, which prevents folding. They can be found on the market in different volumes, can be reused for several cycles, and provide better ergonomics to the customers and workers (Araujo et al., 2018).

Forest species present different growth patterns mediated mainly by their potential to accumulate carbon (dry matter) and perform photosynthesis. Among the species that can be compared, Handroanthus heptaphyllus (Mart.) Mattos (ipê-roxo) from the Bignoniaceae family stands out and an ecological group from the secondary ones with slower growth and Schinus terebinthifolius Raddi (pimenteira) from the Anacardiaceae family, more rustic in the nursery presenting growth potential similar to genetically improved forest species, such as those of the genus Eucalyptus (Araujo et al. 2018). Both are species with characteristics for commercial and environmental (Carvalho 2003; Backes \& Irgang 2009).

As a research hypothesis, it is believed that agro-industrial residues can be used in different proportions to produce seedlings. Thus, this study aimed to evaluate the potential of using substrates formulated with different proportions of agroindustrial residues for H. heptaphyllus and S. terebinthifolius seedling production in two different containers.

\section{MATERIALS AND METHODS}

The study was carried out at the Silviculture and Forest Nursery Laboratory $\left(29^{\circ} 43^{\prime} \mathrm{S}\right.$ and $\left.53^{\circ} 43^{\prime} \mathrm{W}\right)$ of the Federal University of Santa Maria (UFSM), in the municipality of Santa Maria - RS, southern Brazil. According to the Köppen classification, the local climate is Subtropical of the Cfa type, with four well-defined seasons and average annual precipitation and temperature of $1,500-1,600 \mathrm{~mm}$ and $19.2^{\circ} \mathrm{C}$, respectively (Alvares et al., 2013).

For each species, experiments had a completely randomized design with four replications, with a $2 \times 10$ factorial scheme, i.e., two container sizes $\left(110\right.$ and $\left.180 \mathrm{~cm}^{3}\right)$ and ten substrate mixtures (Table 1). Each replication consisted of 48 seedlings, with the 24 central seedlings being used as a useful plot, avoiding border effect.

In this study, the main component in volume was a commercial substrate (CS), an organic compound produced with regional material from viticulture (seeds and grape marc), a small proportion of carbonized rice husk, peat, and vermiculite. The secondary components (conditioners) used were carbonized rice husk (CRH), hydrolyzed rice husk (HRH), and crushed peach pits (CPP).

Table 1. Composition and proportion of components used in the substrate to produce Schinus terebinthifolius and Handroanthus heptaphyllus seedlings in the nursery, Santa Maria, RS.

\begin{tabular}{|cc|}
\hline Treatments & Components/proportion (v:v) \\
\hline T1 $-100 \mathrm{CS}$ & $100 \% \mathrm{CS}$ \\
\hline T2 $-10 \mathrm{CRH}$ & $90 \% \mathrm{CS}$ and $10 \% \mathrm{CRH}$ \\
\hline T3 $-20 \mathrm{CRH}$ & $80 \% \mathrm{CS}$ and $20 \% \mathrm{CRH}$ \\
\hline T4 $-30 \mathrm{CRH}$ & $70 \% \mathrm{CS}$ and $30 \% \mathrm{CRH}$ \\
\hline T5 $-10 \mathrm{HRH}$ & $90 \% \mathrm{CS}$ and $10 \% \mathrm{HRH}$ \\
\hline T6 $-20 \mathrm{HRH}$ & $80 \% \mathrm{CS}$ and $20 \% \mathrm{HRH}$ \\
\hline T7 $-30 \mathrm{HRH}$ & $70 \% \mathrm{CS}$ and $30 \% \mathrm{HRH}$ \\
\hline T8 $-10 \mathrm{CPP}$ & $90 \% \mathrm{CS}$ and $10 \% \mathrm{CPP}$ \\
\hline T9 $-20 \mathrm{CPP}$ & $80 \% \mathrm{CS}$ and $20 \% \mathrm{CPP}$ \\
\hline T10 $-30 \mathrm{CPP}$ & $70 \% \mathrm{CS}$ and $30 \% \mathrm{CPP}$ \\
\hline
\end{tabular}

CS - commercial substrate; $\mathrm{CRH}$ - carbonized rice husk; HRH - hydrolyzed rice husk and CPP - crushed peach pits.

CRH was acquired from local producers, and HRH was produced at the Silviculture and Forest Nursery Laboratory. Rice husk was hydrolyzed by immersing it in natura in drinking water until partial decomposition of organic material. For this, a $1000 \mathrm{~L}$ box was filled up to $10 \mathrm{~cm}$ from the edge with peel, and water was added until the container was filled. At two-day intervals, a water sample was collected to measure $\mathrm{pH}$ and electrical conductivity (EC), and then all water was removed from the container and replaced with clean water. The process was repeated until $\mathrm{pH}, \mathrm{EC}$, and peel sedimentation stabilized. Afterward, the bark was dried in a covered area and stored in bags for later use. The peach pits were purchased at Oderich Company S.A. (canning factory in Rio Grande do Sul, Brazil), dried at room temperature, and crushed in a hammer mill.

Substrate formulation included three proportions (10\%, $20 \%$, and $30 \%$ ) (v:v) of CRH, HRH, and CPP, mixed with $\mathrm{CS}$, resulting in 10 treatments including the control without any conditioner (Table 1).

\subsection{Physical and chemical characterization of the substrates}

The physical properties, $\mathrm{pH}$, and electrical conductivity (EC) (Table 2) were analyzed at the Laboratory of Analysis of Substrates for Plants from the State Foundation for Agricultural Research of Rio Grande do Sul, Porto Alegre, RS. 
Table 2. Physical properties, $\mathrm{pH}$, and electrical conductivity (EC) analyses of commercial substrates (CS) with different combinations of carbonized and hydrolyzed rice husk (CRH and $3 \mathrm{HRH}$, respectively) and crushed peach pits (CPP) to produce S. terebinthifolius and H. heptaphyllus seedlings, Santa Maria, RS.

\begin{tabular}{|c|c|c|c|c|c|c|c|c|}
\hline \multirow{2}{*}{ Substrate } & \multicolumn{8}{|c|}{ Characteristics } \\
\hline & DD $\left(\mathrm{kg} \mathrm{m}^{-3}\right)$ & $\mathrm{TP}\left(\mathbf{m}^{3} \mathbf{m}^{-3}\right)$ & $\operatorname{AS}\left(\mathbf{m}^{3} \mathbf{m}^{-3}\right)$ & WRC & WEA $\left(\mathbf{m}^{3} \mathbf{m}^{-3}\right)$ & BW $\left(\mathbf{m}^{3} \mathbf{m}^{-3}\right)$ & PH & $\mathrm{EC}\left(\mathrm{dS} \mathrm{m}^{-1}\right)$ \\
\hline $100 \mathrm{CS}$ & 270.38 & 0.77 & 0.14 & 62.96 & 22.58 & 4.20 & 5.68 & 0.52 \\
\hline $10 \mathrm{CRH}$ & 252.06 & 0.76 & 0.16 & 60.14 & 23.24 & 4.02 & 5.91 & 0.48 \\
\hline $20 \mathrm{CRH}$ & 252.65 & 0.79 & 0.18 & 61.41 & 24.38 & 3.91 & 5.75 & 0.44 \\
\hline $30 \mathrm{CRH}$ & 237.93 & 0.80 & 0.21 & 58.52 & 24.28 & 3.75 & 5.92 & 0.38 \\
\hline $10 \mathrm{HRH}$ & 268.18 & 0.78 & 0.17 & 61.50 & 22.40 & 4.03 & 5.39 & 0.53 \\
\hline $20 \mathrm{HRH}$ & 246.38 & 0.75 & 0.22 & 53.14 & 18.89 & 3.47 & 5.40 & 0.53 \\
\hline $30 \mathrm{HRH}$ & 232.79 & 0.78 & 0.31 & 47.12 & 17.05 & 2.16 & 5.51 & 0.45 \\
\hline $10 \mathrm{CPP}$ & 322.63 & 0.77 & 0.17 & 59.63 & 21.73 & 3.94 & 5.53 & 0.50 \\
\hline $20 \mathrm{CPP}$ & 354.30 & 0.73 & 0.18 & 54.89 & 19.85 & 2.43 & 5.41 & 0.50 \\
\hline $30 \mathrm{CPP}$ & 402.76 & 0.70 & 0.20 & 49.94 & 17.14 & 2.15 & 5.64 & 0.40 \\
\hline
\end{tabular}

DD, Dry density; TP, Total porosity; AS, Aeration space; WRC, Water retention capacity; WEA, Water easily available; BW - buffering water; $100 \mathrm{CS}, 100 \%$ commercial substrate; $10 \mathrm{CRH}, 90 \% \mathrm{CS}+10 \%$ carbonized rice husk (CRH); $20 \mathrm{CRH}, 80 \% \mathrm{CS}+20 \% \mathrm{CRH} ; 30 \mathrm{CRH}, 70 \% \mathrm{CS}+30 \% \mathrm{CRH} ; 10 \mathrm{HRH}, 90 \% \mathrm{CS}+10 \%$ hydrolyzed rice husk (HRH); $20 \mathrm{HRH}, 80 \% \mathrm{CS}+20 \% \mathrm{HRH} ; 30 \mathrm{HRH}, 70 \% \mathrm{CS}+30 \% \mathrm{HRH} ; 10 \mathrm{CPP}, 90 \% \mathrm{CS}+10 \%$ crushed peach pits (CPP); $20 \mathrm{CPP}, 80 \% \mathrm{CS}+$ $20 \%$ CPP; $30 \mathrm{CPP}, 70 \%$ CS + 30\% CPP.

In each treatment, $8 \mathrm{~g} \mathrm{~L}^{-1}$ of controlled-release fertilizer were added, in the formulation NPK 15-09-12, calcium (Ca), magnesium $(\mathrm{Mg})$, and the micronutrients sulfur $(\mathrm{S})$, boron (B), copper ( $\mathrm{Cu})$, manganese $(\mathrm{Mn})$, iron $(\mathrm{Fe})$ and zinc $(\mathrm{Zn})$. According to the manufacturer, on a humid substrate with an average temperature of $21^{\circ} \mathrm{C}$, nutrient release occurs gradually, between six and eight months.

Sowing was done manually, with three seeds placed in each container (tube) and covered with a thin layer of the substrate. Afterward, the trays were placed in a greenhouse where they received four daily irrigations, totaling $4 \mathrm{~mm}$ day $^{1}$. At 28 days after sowing, when the seedlings showed two to three pairs of leaves, thinning was done, leaving only the most vigorous and central plant per container. At 60 days after sowing, alternation was performed, reducing the seedling density to $50 \%$ of tray capacity, and the irrigation rate was increased to $6 \mathrm{~mm} \mathrm{day}^{-1}$.

The evaluation of the morphological and physiological variables was performed at 90 and 108 days after the emergence of S. terebinthifolius and H. heptaphyllus seedlings, respectively, when the seedlings of one of the treatments had a mean height $(>20 \mathrm{~cm})$ and stem diameter, $(>3 \mathrm{~mm})$, condition recommended in the literature for expedition (Gomes \& Paiva, 2011; Davide et al., 2015; Araujo et al., 2018).

Initially, the aerial part height $(\mathrm{H})$ and stem diameter (SD) were evaluated. Subsequently, three plants per replicate were selected at random, and sectioned into shoot (stem and leaves) and root to obtain shoot, root, and total dry matter (SDM, RDM, and TDM, respectively), leaf area (LA), and Dickson's quality index (DQI). LA was determined with the aid of a digital camera (DSC-T100, SONY) and the image analysis software Image J. To obtain SDM, RDM, and TDM, samples of leaves and roots were placed in kraft paper bags, dried in an oven with air circulation at $65^{\circ} \mathrm{C}$ to constant weight, and then weighed on a precision digital scale $(0.001 \mathrm{~g})$. Based on these data, DQI was determined using equation 1 (Dickson et al., 1960):

$$
D Q I=\frac{T D M}{\left(\frac{H}{D}\right)+\left(\frac{S D M}{R D M}\right)}
$$

DQI - Dickson's quality index; TDM - total dry matter; $\mathrm{H}$ - height; SD - stem diameter; SDM - shoot dry matter and RDM - root dry matter.

Chlorophyll a fluorescence was measured with a JUNIORPAM modulated pulse fluorometer (Walz, Germany) from 08:00 to 10:00 am, using the third expanded sheet of each treatment, after adaptation to the dark in aluminum foil for 30 minutes. Initial (Fo) and maximum (Fm) fluorescence were assessed, and the maximum photochemical efficiency of photosystem II $\left(\mathrm{F}_{v} / \mathrm{F}_{\mathrm{m}}\right)$ was estimated, where $\mathrm{F}_{\mathrm{v}}$ is fluorescence variation $\left(\mathrm{Fv}=\mathrm{F}_{\mathrm{m}}-\mathrm{F}_{\mathrm{o}}\right)$. 
Chlorophyll $\mathrm{a}$ and $\mathrm{b}$ relative levels were obtained with a chlorophyll meter (ClorofiLOG, CF 1030, Falker Agricultural Automation, Brazil) at two points in the middle third from the apex of the plant and expressed with the Falker chlorophyll index (FCI).

Data were checked for assumptions of normality and homogeneity of variance by the Shapiro-Wilk and Bartlett tests $(P>0.05)$, respectively, using the Action supplement. Those data that did not meet the assumptions were transformed by Box-Cox. Afterward, analysis of variance (ANOVA) was performed, means were compared by t-test (containers), and Scott-Knott (substrates) at 5\% probability of error. Analyses were performed using the Sisvar software (Ferreira, 2014).

\section{RESULTS}

\subsection{Performance of Schinus terebinthifolius seedlings}

For S. terebinthifolius, ANOVA detected interaction between container and substrate affecting height $(\mathrm{H})$ and maximum photochemical efficiency of photosystem II $\left(\mathrm{F}_{\mathrm{v}} / \mathrm{F}_{\mathrm{m}}\right)$ ( $P=0.012$ and 0.017 , respectively) (Table 3 ). For the stem diameter (SD), there was an effect of the isolated factors, container $(P<0.001)$ and substrate $(P<0.001)$, while for shoot dry matter (SDM), root dry matter (RDM), total dry matter (TDM), leaf area (LA) and Dickson's quality index (DQI) there was an effect of the container (Table 4).

Table 3. Height $(\mathrm{H})$ and maximum photochemical efficiency of photosystem $\mathrm{II}\left(\mathrm{F}_{\mathrm{v}} / \mathrm{F}_{\mathrm{m}}\right)$ of Schinus terebinthifolius produced in a nursery in Santa Maria, RS, using different containers and substrates, measured 90 days after emergence.

\begin{tabular}{|c|c|c|c|c|}
\hline \multirow{3}{*}{ Substrates } & \multicolumn{2}{|c|}{ Height (cm) } & \multicolumn{2}{|c|}{$F_{v} / F_{m}$} \\
\hline & \multicolumn{4}{|c|}{ Containers $\left(\mathrm{cm}^{3}\right)$} \\
\hline & 110 & 180 & 110 & 180 \\
\hline 100SC & $32.71 \mathrm{Aa}^{*}$ & $33.16 \mathrm{Aa}$ & $0.79 \mathrm{Aa}$ & $0.64 \mathrm{Bb}$ \\
\hline 10CAC & $32.23 \mathrm{Aa}$ & $37.72 \mathrm{Aa}$ & $0.74 \mathrm{Aa}$ & $0.72 \mathrm{Aa}$ \\
\hline 20CAC & $34.60 \mathrm{Aa}$ & $39.94 \mathrm{Aa}$ & $0.76 \mathrm{Aa}$ & $0.74 \mathrm{Aa}$ \\
\hline $30 \mathrm{CAC}$ & $28.48 \mathrm{Bb}$ & $35.91 \mathrm{Aa}$ & $0.78 \mathrm{Aa}$ & $0.77 \mathrm{Aa}$ \\
\hline $10 \mathrm{CAH}$ & $32.79 \mathrm{Aa}$ & $33.64 \mathrm{Aa}$ & $0.79 \mathrm{Aa}$ & $0.78 \mathrm{Aa}$ \\
\hline $20 \mathrm{CAH}$ & $34.95 \mathrm{Aa}$ & $31.66 \mathrm{Aa}$ & $0.74 \mathrm{Aa}$ & $0.77 \mathrm{Aa}$ \\
\hline $30 \mathrm{CAH}$ & $22.44 \mathrm{Bb}$ & $34.38 \mathrm{Aa}$ & $0.64 \mathrm{Bb}$ & $0.75 \mathrm{Aa}$ \\
\hline $10 \mathrm{CPT}$ & $30.36 \mathrm{Aa}$ & $29.64 \mathrm{Aa}$ & $0.77 \mathrm{Aa}$ & $0.75 \mathrm{Aa}$ \\
\hline $20 \mathrm{CPT}$ & $31.12 \mathrm{Aa}$ & $32.14 \mathrm{Aa}$ & $0.71 \mathrm{Ba}$ & $0.74 \mathrm{Aa}$ \\
\hline $30 \mathrm{CPT}$ & $27.58 \mathrm{Bb}$ & $35.53 \mathrm{Aa}$ & $0.71 \mathrm{Ba}$ & $0.70 \mathrm{Ba}$ \\
\hline $\mathrm{CV}(\%)$ & \multicolumn{2}{|c|}{12.57} & \multicolumn{2}{|c|}{7.83} \\
\hline Overall average & \multicolumn{2}{|c|}{32.55} & \multicolumn{2}{|c|}{0.74} \\
\hline
\end{tabular}

* Uppercase and lowercase letters along rows (container) and columns (substrate) indicate significant differences by the t-test and Scott-Knott, respectively, at $5 \%$ probability of error. CS, Commercial substrate; $100 \mathrm{CS}, 100 \%$ commercial substrate; $10 \mathrm{CRH}, 90 \% \mathrm{CS}+10 \%$ carbonized rice husk (CRH); $20 \mathrm{CRH}, 80 \%$ CS $+20 \%$ CRH; 30CRH, 70\% CS + 30\% CRH; 10HRH, 90\% CS + 10\% hydrolyzed rice husk (HRH); $20 \mathrm{HRH}, 80 \% \mathrm{CS}+20 \% \mathrm{HRH} ; 30 \mathrm{HRH}, 70 \% \mathrm{CS}+30 \% \mathrm{HRH}$; $10 \mathrm{CPP}, 90 \%$ $\mathrm{CS}+10 \%$ crushed peach pits (CPP); $20 \mathrm{CPP}, 80 \% \mathrm{CS}+20 \% \mathrm{CPP} ; 30 \mathrm{CPP}, 70 \% \mathrm{CS}+30 \% \mathrm{CPP}$, and CV, coefficient of variation.

Regardless of the container volume $\left(110\right.$ or $\left.180 \mathrm{~cm}^{3}\right)$, most substrates presented results similar to those of 100CS, with those up to $20 \%$ of CRH, HRH or CPP not compromising height growth of S. terebinthifolius seedlings. However, less growth was found in the small container with $30 \%$ mixtures of any conditioner (Table 4). This result was generally confirmed by the lower $\mathrm{F}_{\mathrm{v}} / \mathrm{F}_{\mathrm{m}}$ when the mixture with $30 \%$ $\mathrm{HRH}$ was used in the $110 \mathrm{~cm}^{3}$ container (Table 3).

For the $180 \mathrm{~cm}^{3}$ container, D was $16 \%$ higher than that of the $110 \mathrm{~cm}^{3}$ container. $30 \mathrm{HRH}$ had the lowest D average $(2.79 \mathrm{~mm})$, while those of other substrates did not differ among them (Table 4). 
Table 4. Average stem diameter (SD), shoot (SDM), root (RDM), and total dry matter (TDM), Dickson's quality index (DQI), leaf area (LA) and chlorophyll a and b of $S$. terebinthifolius seedlings produced in different containers and substrates, in a nursery, Santa Maria, RS, meansured 90 days after emergence.

\begin{tabular}{|c|c|c|c|c|c|c|c|c|}
\hline \multirow{2}{*}{$\begin{array}{l}\text { Containers } \\
\qquad\left(\mathrm{cm}^{3}\right)\end{array}$} & \multicolumn{8}{|c|}{ Variables } \\
\hline & $\mathrm{DC}(\mathrm{mm})$ & SDM (g) & RDM (g) & TDM (g) & DQI & LA $\left(\mathrm{cm}^{2}\right)$ & Cla $a$ (ICF) & Cla $b$ (ICF) \\
\hline 110 & $3.19 \mathrm{~b}^{*}$ & $2.0 \mathrm{~b}$ & $0.54 \mathrm{~b}$ & $2.54 \mathrm{~b}$ & $0.19 \mathrm{~b}$ & $27.86 \mathrm{~b}$ & $32.13 \mathrm{~b}$ & $7.72 \mathrm{~b}$ \\
\hline 180 & $3.78 \mathrm{a}$ & $2.77 \mathrm{a}$ & $0.68 \mathrm{a}$ & $3.46 \mathrm{a}$ & $0.26 \mathrm{a}$ & $40.04 \mathrm{a}$ & $33.89 \mathrm{a}$ & $8.48 \mathrm{a}$ \\
\hline \multicolumn{9}{|l|}{ Substrates } \\
\hline $100 \mathrm{CS}$ & $3.57 \mathrm{a}$ & $2.38^{\mathrm{ns}}$ & $0.44^{\mathrm{ns}}$ & $2.82^{\mathrm{ns}}$ & $0.19^{\mathrm{ns}}$ & $34.53^{\text {ns }}$ & $32.16 \mathrm{~b}$ & $8.01 \mathrm{~b}$ \\
\hline $10 \mathrm{CRH}$ & $3.52 \mathrm{a}$ & 2.74 & 0.59 & 3.33 & 0.23 & 40.27 & $34.44 \mathrm{a}$ & $8.91 \mathrm{a}$ \\
\hline $20 \mathrm{CRH}$ & $3.73 \mathrm{a}$ & 2.86 & 0.65 & 3.51 & 0.24 & 40.82 & $34.83 \mathrm{a}$ & $8.99 \mathrm{a}$ \\
\hline $30 \mathrm{CRH}$ & $3.54 \mathrm{a}$ & 2.52 & 0.60 & 3.12 & 0.24 & 34.34 & $35.07 \mathrm{a}$ & $9.11 \mathrm{a}$ \\
\hline $10 \mathrm{HRH}$ & $3.44 \mathrm{a}$ & 2.36 & 0.66 & 3.03 & 0.23 & 34.08 & $34.19 \mathrm{a}$ & $8.39 \mathrm{a}$ \\
\hline $20 \mathrm{HRH}$ & $4.06 \mathrm{a}$ & 2.25 & 0.60 & 2.85 & 0.23 & 33.33 & $32.0 \mathrm{~b}$ & $7.30 \mathrm{~b}$ \\
\hline $30 \mathrm{HRH}$ & $2.79 \mathrm{~b}$ & 2.03 & 0.57 & 2.60 & 0.19 & 30.11 & $32.51 \mathrm{~b}$ & $7.86 \mathrm{~b}$ \\
\hline $10 \mathrm{CPP}$ & $3.55 \mathrm{a}$ & 2.66 & 0.85 & 3.48 & 0.30 & 31.78 & $33.46 \mathrm{a}$ & $8.57 \mathrm{a}$ \\
\hline $20 \mathrm{CPP}$ & $3.41 \mathrm{a}$ & 1.83 & 0.54 & 2.37 & 0.19 & 28.49 & $30.14 \mathrm{~b}$ & $6.66 \mathrm{~b}$ \\
\hline $30 \mathrm{CPP}$ & $3.21 \mathrm{a}$ & 2.25 & 0.63 & 2.87 & 0.21 & 31.71 & $35.06 \mathrm{~b}$ & $7.18 \mathrm{~b}$ \\
\hline CV (\%) & 11.13 & 42.88 & 30.37 & 35.32 & 3.77 & 25.01 & 8.41 & 4.33 \\
\hline Overall average & 3.48 & 2.39 & 0.61 & 3.00 & 0.23 & 33.95 & 33.01 & 8.10 \\
\hline
\end{tabular}

* Lowercase letters along columns indicate statistical difference at $5 \%$ probability of error by the t-test (containers) and Scott-Knott (substrates). CS, Commercial substrate; 100CS, 100\% commercial substrate; 10CRH, 90\% CS + 10\% carbonized rice husk (CRH); $20 \mathrm{CRH}, 80 \% \mathrm{CS}+20 \% \mathrm{CRH} ; 30 \mathrm{CRH}$, $70 \% \mathrm{CS}+30 \% \mathrm{CRH}$; $10 \mathrm{HRH}, 90 \% \mathrm{CS}+10 \%$ hydrolyzed rice husk (HRH); $20 \mathrm{HRH}-80 \% \mathrm{CS}+20 \% \mathrm{HRH} ; 30 \mathrm{HRH}-70 \% \mathrm{CS}+30 \% \mathrm{HRH}$; $10 \mathrm{CPP}, 90 \% \mathrm{CS}+10 \% \mathrm{crushed}$ peach pits (CPP); 20CPP, $80 \%$ CS + 20\% CPP; 30CPP, 70\% CS + 30\% CPP; CV, coefficient of variation, and ns, not significant.

SDM and $\mathrm{RDM}$ in the $180 \mathrm{~cm}^{3}$ container were $28 \%$ and $21 \%$ higher than those in the $110 \mathrm{~cm}^{3}$ container, respectively, with no difference among substrates (Table 4). For TRM, DQI, and LA, the highest averages were observed in the 180 $\mathrm{cm}^{3}$ container, being $21 \%, 27 \%$, and $30 \%$ higher than those in the $110 \mathrm{~cm}^{3}$ container, respectively. However, there was no difference among substrates (Table 4 ).

Among the physiological variables, there was the effect of container and substrate $(P=0.006$ and 0.02 , respectively) on FCI $a$ and $b$. For the $180 \mathrm{~cm}^{3}$ container there was a more significant increase in chlorophyll $a$ and $b$ (FCI $=33.89$ and 8.48 , respectively) than the 110 $\mathrm{cm}^{3}$ container. Regarding the substrates, the means of chlorophyll $a$ and $b$ in substrate 100CS and those with
$20 \%$ and $30 \% \mathrm{HRH}$ or CPP were lower than those in other substrates (Table 4).

\subsection{Performance of Handroanthus heptaphyllus seedlings}

The morphological attributes of $H$. heptaphyllus seedlings, such as SDM, TDM, and LA, were influenced by the interaction between container and substrate (Table 5). Furthermore, there were independent effects on $\mathrm{H}, \mathrm{D}, \mathrm{H} / \mathrm{D}$ ratio, $\mathrm{RDM}$, and $\mathrm{DQI}$ (Table 6). High SDM $(P=0.02)$ and TDM $(P=0.02)$ were found in the $180 \mathrm{~cm}^{3}$ containers with CRH in any proportion, $20 \%$ $\mathrm{HRH}$, or $10 \% \mathrm{CPP}$, while the highest LA $(P=0.01)$ occurred only with $100 \mathrm{CS}$ and $10 \% \mathrm{CRH}$ (Table 5). 
Table 5. Shoot (SDM) and total dry matter (TDM) and leaf area (LA) of H. heptaphyllus seedlings produced in different container volumes and substrates in the nursery, Santa Maria, RS, at 108 days after emergence.

\begin{tabular}{|c|c|c|c|c|c|c|}
\hline \multirow{3}{*}{ Substrates } & \multicolumn{2}{|c|}{ SDM (g) } & \multicolumn{2}{|c|}{ TDM $(\mathrm{g})$} & \multicolumn{2}{|c|}{ LA $\left(\mathrm{cm}^{2}\right)$} \\
\hline & \multicolumn{6}{|c|}{ Containers $\left(\mathrm{cm}^{3}\right)$} \\
\hline & 110 & 180 & 110 & 180 & 110 & 180 \\
\hline $100 \mathrm{CS}$ & $1.98 \mathrm{Bb}^{*}$ & $3.33 \mathrm{Aa}$ & $2.98 \mathrm{Ba}$ & $4.63 \mathrm{Aa}$ & $371.26 \mathrm{Bb}$ & $597.50 \mathrm{Aa}$ \\
\hline 10CRH & $2.03 \mathrm{Ba}$ & $3.41 \mathrm{Aa}$ & $3.03 \mathrm{Ba}$ & $4.70 \mathrm{Aa}$ & $360.56 \mathrm{Bb}$ & $612.90 \mathrm{Aa}$ \\
\hline $20 \mathrm{CRH}$ & $2.15 \mathrm{Ba}$ & $3.09 \mathrm{Ac}$ & $3.19 \mathrm{Ba}$ & $4.52 \mathrm{Aa}$ & $404.20 \mathrm{Ba}$ & $518.57 \mathrm{Ab}$ \\
\hline $30 \mathrm{CRH}$ & $2.20 \mathrm{Ba}$ & $3.18 \mathrm{Ab}$ & $3.39 \mathrm{Ba}$ & $4.35 \mathrm{Aa}$ & $397.94 \mathrm{Ba}$ & $555.79 \mathrm{Ab}$ \\
\hline $10 \mathrm{HRH}$ & $2.09 \mathrm{Ba}$ & $2.85 \mathrm{Ac}$ & $3.15 \mathrm{Ba}$ & $4.07 \mathrm{Aa}$ & $372.35 \mathrm{Ba}$ & $523.28 \mathrm{Ab}$ \\
\hline $20 \mathrm{HRH}$ & $1.81 \mathrm{Bc}$ & $3.17 \mathrm{Ab}$ & $3.01 \mathrm{Ba}$ & $4.63 \mathrm{Aa}$ & $314.27 \mathrm{Bc}$ & $508.18 \mathrm{Ab}$ \\
\hline $30 \mathrm{HRH}$ & $2.11 \mathrm{Aa}$ & $2.39 \mathrm{Ad}$ & $3.09 \mathrm{Aa}$ & $3.31 \mathrm{Ab}$ & $406.48 \mathrm{Aa}$ & $425.04 \mathrm{Ac}$ \\
\hline $10 \mathrm{CPP}$ & $1.90 \mathrm{Bb}$ & $2.92 \mathrm{Ac}$ & $3.03 \mathrm{Ba}$ & $4.38 \mathrm{Aa}$ & $308.75 \mathrm{Bc}$ & $495.78 \mathrm{Ab}$ \\
\hline $20 \mathrm{CPP}$ & $1.27 \mathrm{Bc}$ & $2.50 \mathrm{Ad}$ & $2.02 \mathrm{Bb}$ & $3.68 \mathrm{Ab}$ & $238.18 \mathrm{Bc}$ & 435.39 Ac \\
\hline $30 \mathrm{CPP}$ & $1.13 \mathrm{Bc}$ & $1.95 \mathrm{Ad}$ & $1.93 \mathrm{Bb}$ & $2.89 \mathrm{Ab}$ & $215.06 \mathrm{Bc}$ & $356.42 \mathrm{Ac}$ \\
\hline CV (\%) & & & & & & \\
\hline Overall average & & & & & & \\
\hline
\end{tabular}

* Uppercase and lowercase letters along rows (container) and columns (substrate) indicate statistically significant differences at $5 \%$ probability of error by the t-test and Scott-Knott, respectively. CS, commercial substrate; 100CS, $100 \%$ commercial substrate; $10 \mathrm{CRH}, 90 \%$ CS + 10\% carbonized rice husk (CRH); $20 \mathrm{CRH}, 80 \%$ CS + $20 \%$ CRH; $30 \mathrm{CRH}, 70 \% \mathrm{CS}+30 \% \mathrm{CRH} ; 10 \mathrm{HRH}-90 \% \mathrm{CS}+10 \%$ hydrolyzed rice husk (HRH); $20 \mathrm{HRH}-80 \% \mathrm{CS}+20 \% \mathrm{HRH} ; 30 \mathrm{HRH}-70 \% \mathrm{CS}+30 \% \mathrm{HRH}$; $10 \mathrm{CPP}, 90 \% \mathrm{CS}+10 \%$ crushed peach pits (CPP); $20 \mathrm{CPP}, 80 \% \mathrm{CS}+20 \% \mathrm{CPP} ; 30 \mathrm{CPP}, 70 \% \mathrm{CS}+30 \% \mathrm{CPP}$, and CV, coefficient of variation.

Table 6. Mean values for height $(\mathrm{H})$, stem diameter (SD), root dry matter (RDM), Dickson's quality index (DQI), chlorophyll $b$, and maximum photochemical efficiency of photosystem II $\left(\mathrm{F}_{\mathrm{v}} / \mathrm{F}_{\mathrm{m}}\right)$ of $H$. heptaphyllus seedlings in different containers and substrates, 108 days after emergence, in a nursery, Santa Maria, RS.

\begin{tabular}{|c|c|c|c|c|c|c|}
\hline \multirow[b]{2}{*}{ Containers $\left(\mathrm{cm}^{3}\right)$} & \multicolumn{6}{|c|}{ Variables } \\
\hline & $\mathrm{H}(\mathrm{cm})$ & $\mathrm{SD}(\mathrm{mm})$ & RDM (g) & DQI & Chlorophyll $b$ & $\mathrm{~F}_{\mathrm{v}} / \mathrm{F}_{\mathrm{m}}$ \\
\hline 110 & $18,67 \mathrm{~b}$ & $3,20 \mathrm{~b}$ & $1,02 \mathrm{~b}$ & $0,36 \mathrm{~b}$ & $4,38 \mathrm{~b}$ & $0,64^{\mathrm{ns}}$ \\
\hline 180 & 25,15 a & $3,73 \mathrm{a}$ & $1,24 \mathrm{a}$ & $0,45 \mathrm{a}$ & 5,03 a & 0,62 \\
\hline \multicolumn{7}{|l|}{ Substrates } \\
\hline $100 \mathrm{CS}$ & 24,52 a & $3,60 \mathrm{a}$ & $1,15 \mathrm{a}$ & $0,42 \mathrm{a}$ & $4,39^{\mathrm{ns}}$ & $0,69 \mathrm{a}$ \\
\hline 10CRH & 24,15 a & $3,81 \mathrm{a}$ & $1,15 \mathrm{a}$ & $0,44 \mathrm{a}$ & 4,66 & $0,64 \mathrm{a}$ \\
\hline $20 \mathrm{CRH}$ & 23,14 a & $3,68 \mathrm{a}$ & $1,23 \mathrm{a}$ & $0,46 \mathrm{a}$ & 4,41 & $0,69 \mathrm{a}$ \\
\hline $30 \mathrm{CRH}$ & 23,59 a & $3,53 \mathrm{a}$ & $1,18 \mathrm{a}$ & $0,44 \mathrm{a}$ & 4,84 & $0,66 \mathrm{a}$ \\
\hline $10 \mathrm{HRH}$ & $21,56 \mathrm{~b}$ & $3,42 \mathrm{~b}$ & $1,14 \mathrm{a}$ & $0,43 \mathrm{a}$ & 5,11 & $0,68 \mathrm{a}$ \\
\hline $20 \mathrm{HRH}$ & $21,35 \mathrm{~b}$ & $3,44 \mathrm{~b}$ & $1,33 \mathrm{a}$ & $0,47 \mathrm{a}$ & 4,73 & $0,61 \mathrm{~b}$ \\
\hline $30 \mathrm{HRH}$ & $21,93 \mathrm{~b}$ & $3,40 \mathrm{~b}$ & $0,95 \mathrm{~b}$ & $0,36 \mathrm{~b}$ & 5,31 & $0,64 \mathrm{a}$ \\
\hline $10 \mathrm{CPP}$ & $22,5 b$ & $3,46 \mathrm{~b}$ & $1,30 \mathrm{a}$ & $0,44 \mathrm{a}$ & 4,36 & $0,61 \mathrm{~b}$ \\
\hline $20 \mathrm{CPP}$ & $19,79 \mathrm{c}$ & $3,21 \mathrm{c}$ & $0,96 \mathrm{~b}$ & $0,35 \mathrm{~b}$ & 4,39 & $0,57 \mathrm{~b}$ \\
\hline $30 \mathrm{CPP}$ & $16,61 \mathrm{~d}$ & $3,09 \mathrm{c}$ & $0,87 \mathrm{~b}$ & $0,34 \mathrm{~b}$ & 4,83 & $0,53 \mathrm{~b}$ \\
\hline CV (\%) & 9,67 & 7,22 & 19,94 & 16,32 & 6,63 & 12,92 \\
\hline Overall average & 21,91 & 3,47 & 1,13 & 0,41 & 4,7 & 0,63 \\
\hline
\end{tabular}

* Uppercase and lowercase letters along rows (container) and columns (substrate) indicate statistically significant differences at $5 \%$ probability of error by the $\mathrm{t}$-test and Scott-Knott, respectively. CS, commercial substrate; 100CS, $100 \%$ commercial substrate; $10 \mathrm{CRH}, 90 \%$ CS + 10\% carbonized rice husk (CRH); $20 \mathrm{CRH}, 80 \%$ CS + 20\% CRH; 30CRH, $70 \%$ CS + 30\% CRH; $10 \mathrm{HRH}-90 \% \mathrm{CS}+10 \%$ hydrolyzed rice husk (HRH); $20 \mathrm{HRH}-80 \% \mathrm{CS}+20 \% \mathrm{HRH} ; 30 \mathrm{HRH}-70 \% \mathrm{CS}+30 \% \mathrm{HRH}$; $10 \mathrm{CPP}, 90 \% \mathrm{CS}+10 \%$ crushed peach pits (CPP); $20 \mathrm{CPP}, 80 \% \mathrm{CS}+20 \% \mathrm{CPP} ; 30 \mathrm{CPP}, 70 \% \mathrm{CS}+30 \% \mathrm{CPP}$, and CV, coefficient of variation. 
For all attributes showing differences $(P<0.05)$ between containers, when analyzed as an isolated factor, the seedlings produced in the large container were superior to those from the small container (Table 6). On average, seedling height and SDM in the $180 \mathrm{~cm}^{3}$ tube were $26 \%$ and $18 \%$ higher, respectively, than those in the $110 \mathrm{~cm}^{3}$ container (Table 6).

With substrates $100 \mathrm{CS}$ and CRH $(10 \%, 20 \%$, and $30 \%)$, seedlings had the highest height and stem diameter average ( $23.85 \mathrm{~cm}$ and $3.63 \mathrm{~mm}$, respectively), while SDM and DQI were responsive with $100 \mathrm{CS}$, up to $20 \% \mathrm{HRH}$, and $10 \%$ CPP (Table 6).

There was no interactive effect of container and substrate on the physiological attributes. However, there was an independent effect of each factor on the chlorophyll $b$ index and $\mathrm{F}_{\mathrm{v}} / \mathrm{F}_{\mathrm{m}}$. Meanwhile, chlorophyll $a$ index showed no response $(P=0.09)$ to any tested factor.

For chlorophyll $b$, the $180 \mathrm{~cm}^{3}$ container $(P=0.008)$ enabled the highest average index, which did not differ between substrates (Table 6). $\mathrm{F}_{\mathrm{v}} / \mathrm{F}_{\mathrm{m}}$ showed no difference between containers, however, it was bigger with substrates $100 \mathrm{CS}, \mathrm{CRH}$ $(10 \%, 20 \%$, and $30 \%)$, and HRH (10\% and 30\%) (Table 6).

\section{DISCUSSION}

In general, for both forest species, the $180 \mathrm{~cm}^{3}$ container supported greater growth than the $110 \mathrm{~cm}^{3}$ container considering most attributes, showing that medium-toslow growth species (Araujo et al., 2018) responded to the largest available space for the system root growth. S. terebinthifolius seedlings showed greater growth and plasticity to the container than those of $H$. heptaphyllus. However, S. terebinthifolius and H. heptaphyllus presented plants with adequate size for dispatch at 90 and 108 days, respectively, using substrates with up to $30 \% \mathrm{CRH}$ or $\mathrm{HRH}$ and $10 \% \mathrm{CPP}$. These results were compatible with those of $\mathrm{CS}$, and within the minimum size standard $(\mathrm{H}>20 \mathrm{~cm}$ and $\mathrm{SD}>3 \mathrm{~mm}$ ) for native forest species (Gomes \& Paiva, 2011; Davide et al., 2015; Araujo et al., 2018).

Regarding other morphological attributes, S. terebinthifolius always showed better values than $H$. heptaphyllus in substrates with up to $30 \% \mathrm{CRH}$, and $20 \% \mathrm{HRH}$ or $\mathrm{CPP}$, including $\mathrm{F}_{\mathrm{v}} / \mathrm{F}_{\mathrm{m}}$ with $20 \%$ of HRH and CPP, despite the decrease in chlorophylls.

However, specifically considering RDM and DQI in H. heptaphyllus, $\mathrm{HRH}$ restriction of seedling growth was higher at $30 \%$ than that using other proportions. This alternative component also provided the best growth at $10 \%$ and $20 \%$ in a previous study for the genus Eucalyptus (Fermino et al., 2018). For the production of Eucalyptus dunnii Maiden seedlings, Mieth et al. (2018) studied CPP as an alternative substrate component with the same granulometry used in this study, and found similar results, i.e., optimal CPP proportions of $10 \%$ and $20 \%$.

The mean height and stem diameter of both species in all substrates (Tables 4,5 , and 6 ) were within those recommended by the literature of $\mathrm{H}>20 \mathrm{~cm}$ and $\mathrm{SD}>3 \mathrm{~mm}$ (Gomes \& Paiva, 2011; Davide et al., 2015; Araujo et al., 2018), except for those with CPP $20 \%$ and $30 \%$ for $H$. heptaphyllus seedlings.

Alves \& Freire (2017) studied the initial growth and quality of $H$. heptaphyllus seedlings produced in different proportions of substrates (soil, cattle manure, coconut powder, $\mathrm{CRH}$, and commercial substrate) at 210 days in the nursery and reported growth of $8.32 \mathrm{~cm}$ and $3.56 \mathrm{~mm}$ for height and stem diameter, respectively, with height being lower than that indicated as suitable for seedling dispatch to the field. The substrates used in the present study (Table 6) showed better results than the ones verified by Alves \& Freire (2017). In this context, Aimi et al. (2016) mention that the environmental conditions, management, evaluated parameters, and seedling length of stay in the nursery influence the final seedling quality.

In an evaluation of the average monthly height and stem diameter increment (Inc) of native species seedlings, Araujo et al. (2018) classified H. heptaphyllus seedlings, produced with similar environmental conditions (spring/ summer), after 120 days in the nursery, as a species with slow to intermediate growth (Inc $=1.86-4.76 \mathrm{~cm} \mathrm{month}^{-1}$ and $0.42-1.85 \mathrm{~mm}^{\mathrm{month}}{ }^{-1}$ for height and stem diameter, respectively). However, in this study, also carried out in the spring/summer, $H$. heptaphyllus growth was intermediate to rapid, according to the Araujo et al. (2018) classification (Inc $=6.26 \mathrm{~cm} \mathrm{month}^{-1}$ and $0.99 \mathrm{~mm} \mathrm{month}^{-1}$ for height and stem diameter, respectively). It should be noted that the inputs used for seedling production were different and from various sources, which suggests the superiority of the substrates used in this study.

The $\mathrm{H}$ and $\mathrm{SD}$ are the most common morphological attributes used to assess the forest seedlings' quality in nurseries, owing to the method's simplicity, low costs and considering it does not destroy the seedlings (Araujo et al., 2018; Melo et al., 2018). Consequently, it is challenging to establish reference values (default) for most other attributes (Araujo et al., 2018).

Regarding the container, although the $180 \mathrm{~cm}^{3}$ tube supported greater growth for the morphological attributes evaluated, the $110 \mathrm{~cm}^{3}$ container can also be used, saving about $40 \%$ substrate volume. Substrate selection must consider both economy and how much time seedlings may remain in the nursery without compromising their root system, mainly because nurseries that produce native species need great flexibility over dispatch time. 
In H. heptaphyllus, the different water and nutritional demands of seedlings may have reduced growth with $20 \% \mathrm{CRH}$, which is associated with the lower WEA $\left(18.89 \mathrm{~m}^{3} \mathrm{~m}^{-3}\right)$ concerning those of other substrates, consequently providing lower quantum yield when cultivated. Kämpf (2005) highlights three crucial functions of water: hydration, solvent, and means of transport. Water is a fundamental factor for plant life, as it is part of photosynthetic processes (Taiz et al., 2017). During this process, carbon dioxide (CO2) diffuses atmospheric carbon in the leaves through the stomata where it is converted into sugars. However, while $\mathrm{CO} 2$ is diffused in the leaves, the water is distributed outside through transpiration, and plants can reduce transpiration by stomatal closure (Ritchie et al., 2010).

The study suggests that containers with greater volume produce higher-quality seedlings, including for rustic species such as S. terebinthifolius. Abreu et al. (2017), producing seedlings in $280 \mathrm{~cm}^{3}$ containers with a substrate based on biosolids and commercial substrate (50:50, v:v), found that $S$. terebinthifolius seedling height at 134 days after emergence was higher than that of $H$. heptaphyllus ( 38.2 and $21.7 \mathrm{~cm}$, respectively). These findings corroborate our results and the possibility of faster dispatch for S. terebinthifolius seedlings.

The higher averages of biomass parameters (SDM, $\mathrm{RDM}$, and TDM) observed in the largest container are justified by the accessibility to WEA and water retention capacity (WRC), which optimized plant growth. The higher production of biomass reflects the quality of seedlings. Lisboa et al. (2012) reported similar results evaluating the influence of container volume on seedling growth in forest species, obtaining the highest averages in the largest containers ( 180 and $280 \mathrm{~cm}^{3}$ ), owing to the greater availability of water and nutrients.

According to this and several other studies evaluating the influence of container volume, the largest containers produce seedlings of higher growth and better morphological quality (Gasparin et al., 2014; Aimi et al., 2016; Ferreira et al., 2017; Melo et al., 2018). In this study, the morphological quality of seedlings produced in the larger substrate volume supports both species' to grow in the nursery, accelerating the seedling's dispatch to planting.

S. terebinthifolius dry matter production did not differ among the studied substrates. For substrate $20 \mathrm{CRH}$, aeration space (AS) and WRC were $18 \%$ and $61 \%$, respectively, which may have favored root production and, consequently, SDM. For CRH and CPP, the best proportion for biomass production was $10 \%$, resulting in $17 \%$ AS and $62 \%$ and $60 \%$ WRC, respectively (Table 2). Thus, the conditioner proportion was directly related to the aeration space the range between $17 \%$ and $18 \%$ is recommended. However, H. heptaphyllus dry matter production responded differently to the substrates, as SDM, RDM, and TDM were low in the substrates, since with $30 \% \mathrm{HRH}$ and $20 \%$ or $30 \% \mathrm{CPP}$, which can be explained by the characteristics of the substrates.

Regan (2014) indicates that the ideal AS range varies from $10 \%$ to $30 \%$, met by all substrates used in this study. Possibly, the lower quality of the seedlings produced with $20 \%$ CPP and 30\% CPP substrates was correlated with the increase of substrate density, which, together with the reduced WRC, limited the water availability for plants, as observed by Navroski et al. (2014) and Mieth et al. (2018).

In this study, DQI ranged from 0.34 to 0.47 , and those from substrates with $30 \% \mathrm{HRH}$, and $20 \%$ or $30 \% \mathrm{CPP}$ were lower than those of other treatments for H. heptaphyllus. Possibly, the low dry matter production in these treatments decreased DQI, as TDM was used to calculate this attribute. For S. terebinthifolius, DQI did not differ among substrates but differed between containers (0.19 and 0.26) (Table 4). The indicative minimum DQI value of 0.20 (Gomes \& Paiva, 2011) was only obtained in $180 \mathrm{~cm}^{3}$ containers for this species.

In this study, S. terebinthifolius was metabolically more effective in harnessing light, with lower loss by fluorescence $\left(\mathrm{F}_{\mathrm{v}} / \mathrm{F}_{\mathrm{m}}=0.77\right)$ than $H$. heptaphyllus. According to the literature, $F_{v} / F_{m}$ for forest species ranges between 0.75 and 0.85 (Araújo \& Deminicis, 2009). Furthermore, Ritchie et al. (2010) considered 0.70 to 0.83 as values within the normal $\mathrm{F}_{\mathrm{v}} / \mathrm{F}_{\mathrm{m}}$ range, with values below 0.60 indicating a possible stress situation and reducing the photosynthetic potential in plants. For $H$. heptaphyllus, $\mathrm{F}_{\mathrm{v}} / \mathrm{F}_{\mathrm{m}}$ was lowest with the highest CPP proportion, which was not associated with the chlorophyll content.

Regarding the Falker chlorophyll index $a$ and $b$ for S. terebinthifolius, the substrate with $10 \%, 20 \%$ and $30 \%$ CAC, $10 \%$ CAH and CPT were the ones that presented the best averages. However, for $H$. heptaphyllus the treatments were similar for both chlorophyll $a$ and $b$, which indicates that the evaluated substrates did not affect this index and the seedlings that showed less growth. The physiological attributes indicate the metabolic state of the plant and these represent a momentary condition of the plant (Ritchie et al., 2010; Araujo et al., 2018).

In general, rice husk and peach pits are materials made available by the agribusiness and can be used as components of the substrate, reducing seedling production costs in nurseries. Also, used in low proportions, as observed in this study, they can improve the substrates' physical characteristics, contributing positively to the environment. 


\section{CONCLUSIONS}

For Schinus terebinthifolius and Handroanthus heptaphyllus seedling production, the $180 \mathrm{~cm}^{3}$ container is recommended as it provided better seedling growth in the nursery.

Commercial substrates mixed with agro-industrial residues in formulations with up to $20 \%$ of carbonized rice husks (CRH), hydrolyzed rice husks (HRH), or crushed peach pits (CPP) are recommended for Schinus terebinthifolius seedling production, and those with up to $30 \% \mathrm{CRH}$ or $10 \% \mathrm{HRH}$ and CPP are recommended for Handroanthus heptaphyllus seedling production.

\section{SUBMISSION STATUS}

Received: 27 Oct. 2020

Accepted: 08 Mar. 2021

Associate editor: José Carlos Arthur Junior (D)

\section{CORRESPONDENCE TO}

\section{Luciana Samuel Nhantumbo}

Universidade Lúrio, Bairro de Marrere, 4250, Nampula, Mozambique e-mail: luciana91nhantumbo@gmail.com

\section{REFERENCES}

Abreu AHM, Leles PSS, Melo LA, Oliveira RR, Ferreira DHAA. Caracterização e potencial de substratos formulados com biossólido na produção de mudas de Schinus terebinthifolius Raddi. e Handroanthus heptaphyllus (Vell.) Matto. Ciência Florestal 2017; 27: 1179-1190.

Aimi SC, Araujo MM, León EB, Oliveira GG, Cunha FS. Volumen de contenedores y dosis de fertilizante de liberación controlada en el crecimiento de plantas de Cabralea canjerana producidas en vivero. Bosque 2016; 37: 401-407.

Alvares CA, Stape JL, Sentelhas PC, de Moraes Gonçalves JL, Sparovek G. Köppen's climate classification map for Brazil. Meteorol Z. 2013; 22: 711-728.

Alves FJB, Freire ALO. Crescimento inicial e qualidade de mudas de ipê-roxo (Handroanthus impetiginosus (Mart. ex DC) Mattos) produzidas em diferentes substratos. Agro Cient S C S Tec R 2017; ISSN: $1808-6845$.

Araujo MM, Navroski MC, Schorn LA, Tabaldi LA, Rorarto DG, Turchetto $\mathrm{F}$ et al. Caracterização e análise de atributos morfológicos e fisiológicos indicadores da qualidade de mudas em viveiro florestal. In Araujo MM, Navroski MC, Schorn LA. Produção de sementes e mudas: um enfoque à silvicultura. Santa Maria; 2018.

Araújo SAC, Deminicis BB. Fotoinibição da Fotossíntese. Rev Brasileira de Biociências 2009; 7: 463-472.

Backes P, Irgang P. Árvores do sul: guia de identificação e interesse ecológico. Porto Alegre: ed. Paisagem do Sul. 2009.

Bonaguro JE, Coletto L, Zanin G. Environmental and agronomic performance of fresh rice hulls used as growing medium component for Cyclamen persicum L. pot plants. J Cleaner Production 2017; 142: 2125-2132.
Chu EY, Duarte MLR, Tremacoldi CR. Uso da Casca de Arroz Carbonizada como Substrato para Micorrização de Mudas de Três Cultivares de Pimenteira-do-Reino. Embrapa Amazônia Oriental Belém 2007; 66: 1517-2228.

Davide AC and Botelho SA. Fatores que afetam a qualidade de mudas destinadas aos projetos de restauração de ecossistemas florestais. In Davide AC and Botelho SA. Fundamentos e métodos de restauração de ecossistemas florestais: 25 anos de experiência em matas ciliares. Lavras; 2015.

Dickson AS, Leaf D, Hosner JF. Quality appraisal of White spruce and white pine seedling stock in nurseries. Forestry Chronicle 1960; 36: 10-13.

Diniz J, Cardoso AL, Stahl JÁ, Villetti MA, Martins AF. Poder calorífico de casca de arroz, carroço de pêssego, serragem de eucalipto e de seus produtos de pirólise. Ciência e Natura 2004; 26: 25-32.

Fermino MH, Araujo MM, Aimi SC, Turchetto F, Berghetti ALP, Zavistanovicz TC, Mieth P, Griebeler AM, Vilella JMV. Reutilization of residues as components of substrate for the production of Eucalyptus grandis seedlings. Cerne 2018; 24: 80-89.

Ferreira DF. Sisvar: a Guide for its Bootstrap procedures in multiple comparisons. Ciência e Agrotecnologia 2014; 38:109-112.

Ferreira MS, Santos JZL, Tucci CAF, Costa LV. Crescimento inicial de itaúba e macacaúba em recipientes de diferentes tamanhos. Ciência Florestal 2017; 27:499-508.

Gasparin E, Avila AL, Araujo MM, Cargnelutti AF, Dorneles DU. Influência do substrato e do volume de recipiente na qualidade das mudas de Cabralea canjerana (Vell.) Mart. em viveiro e no campo. Ciência Florestal 2014; 24:553-563.

Gomes JM and Paiva HN. Viveiros florestais (Propagação sexuada). Cadernos didáticos. Viçosa; 2011

Islabão GO, Ledemar CV, Timm LC, Paul DL, Kath AH. Rice husk ash as corrective of soil acidity Revista Brasileira de Ciências do Solo 2014; 38: 934-941.

Kämpf AN. Produção comercial de plantas ornamentais. Guaíba Agrolivros; 2005.

Kratz D. Substratos renováveis na produção de mudas de Eucalyptus benthamii Maiden et Cambage e Mimosa scabrella Benth. Curitiba 2011.

Kratz D, Pires PP, Stuepp CA, Wendling I. Produção de mudas de erva-mate por miniestaquia em substratos renováveis. Floresta Curitiba 2015; 45: 609-616.

Landis TD. Containers: types and functions. In: Landis TD, Dumroese RK, Haase DL (eds) The container tree nursery manual. Agriculture Handbook. Department of Agriculture, Forest Service, Washington; 1990.

Lisboa AC, Santos PS, Neto SNO, Castro DN, Abreu AHM. Efeito do volume de tubetes na produção de mudas de Calophyllum brasiliense e Toona Ciliata. Revista Árvore, Viçosa 2012; 36: 603-609.

Melo LA, Abreu AHM, Leles PSS, Oliveira RR, Silva DT. Qualidade e crescimento inicial de mudas de Mimosa caesalpiniifolia benth. produzidas em diferentes volumes de recipientes. Ciência Florestal, Santa Maria 2018; 28: 47-55.

Navroski MC, Araujo MM, Cunha FS, Berguetti ALP, Pereira MO. Influence of hidroretentor polymer in the survival of Eucalyptus dunnii seedlings under different water management. Nativa 2014; $2: 108-113$. 
Mieth P, Araujo MM, Fermino MH, Aimi SC, Gomes DR, Vilella JM. Ground peach pits: alternative substrate component for seedling production. Journal of Forestry Research 2018; 1-13.

Protas JFS, Madail JCM.. Características econômicas e sociais da produção de pêssego no Rio Grande do Sul. In: Sistema de Produção de Pêssego de Mesa na Região da Serra Gaúcha. Embrapa, Brasil. [cited 2018 nov. 25] Available from: https:// sistemasdeproducao.cnptia.embrapa.br/FontesHTML/Pessego/ PessegodeMesaRegiaoSerraGaucha/.

Regan R. Evaluating alternative growing media components. In: Wilkinson KM et al.: 2013 National proceedings: forest and conservation nursery associations. Fort Collins (CO): USDA Forest Service, Rocky Mountain Research Station; 2014.

Ritchie GA, Landis TD, Dumroese RK, Haase DL. Assessing plant quality. Seedling processing, storage, and outplanting, vol 7. Department of Agriculture Forest Service, Washington; 2010.

Silva RF, Eitelwein MT, Cherubin MR, Fabbris C, Weirich S, Pinheiro RR. Produção de mudas de Eucalyptus grandis em substratos orgânicos alternativos. Ciência Florestal, Santa Maria 2014; 24: 609-619.

Taiz L, Zeiger E, Møller IM, Murphy A. Fisiologia e desenvolvimento vegetal. 6th ed. Porto Alegre: Artmed; 2017.

Vieira CR. Resíduos Orgânicos como Substrato para Produção de Mudas de Guanandi. Mato Grosso, Uniciências 2014; 18: 91-97. 